\title{
$X V$. Description of a new-invented astronomical instrument, for placing globes in a proper situation, by means of the Sun, without the help of a magnetic compass, or other instrument
}

\author{
Mr. B.M. Forster
}

To cite this article: Mr. B.M. Forster (1802) XV. Description of a new-invented astronomical instrument, for placing globes in a proper situation, by means of the Sun, without the help of a magnetic compass, or other instrument, Philosophical Magazine Series 1, 12:45, 83-84, DOI: $10.1080 / 14786440208676028$

To link to this article: http://dx.doi.org/10.1080/14786440208676028

$$
\text { 曲 Published online: } 18 \text { May } 2009 .
$$

Submit your article to this journal ए

\section{山 Article views: 3}

Q View related articles ¿ 
I'iazzi would be made by fome diligent aftronomer; and the opinion has been lately revived by Mr. Capel Lofft, a gentleman well known for his attachment both to the foiences and the mufes. In the New London Review for March 1800, this gentleman, in a critique on the Athenian Letters, ventured to offer fome conjectures refpecting an intermediate planet between Mars and Jupiter, the coincidence of which with the new difcovery is very remarkable. He fuppofed that the ditance of the intermediate planet from the Sun would be to that of Mars, either as 33 to 15 , or as 20 to 15 , the midway between which corretponds nearly with the fact. With refpect to its diameter, he conceived it might be to that of Mars, as that of Mars to the diameter of the earth; and then being not much more than half the diameter of Mars, and at five times the perigean diftance, it would be feen from the Earth under an angle of $2_{2}^{1 / 1}$ or $3^{\prime \prime}$, while Georgium sidus would appear under an angle of 4 ". Thefe lucky conjectures were drawn from a certain kind of Pytbagorean harmony, and are ingenioully defended in the Review juft mentioned."

XV. Defription of a new-invented Aftronomical Inftument, for placing Gloles in a proper Situation, by means of the Sun, reitbout the Help of a Magnetic Compajs, or other Iriftrincent. By Mr. B. M. Fonsten *

\section{I}

T confits of a brafs circle, C,C, (Plate II. fig. 2 and 3. ) made to lit the furface of a twelve-inch globe. Acrofs this circle is a brafs bar, $B, B$, arched on the under part, to fit the curve of the globe, and that at the top. The fides of this bar are graduated, anfwering to ten degrees of the ecliptic ; and the under part is chamfered fo, that the edge may be very narrow which lies over the ecliptic, when in ufe. On the flat top of the bar is a fmall hole, with a metal pin S, ferving as a $f f_{y} l_{e}$ to calt a thadow. The part which receires the hadow is painted a dead-white, to prevent the dazzling which the brafs alone would have occafioned.

This little inftrument, which may be called a folar flyle, was made under nyy direction by Mr. Blunt of Cornhill.

\section{Mettod of ufing the Infrument.}

Find the fun's place in the ecliptic, by an almanac, (or on the wooden lyorizon of the globe, if marked there,) then place the inftrument in fuch a manner on the furface of the globe that the pin or flyle be exactly over that place on the ecliptic. Having done this, turn the globe into fuch a

* Communicated by the . uthor. $\mathrm{F}_{2}$

fituation 
Philo.Mag. PL.II. Vol XII.

Fig. 2 .

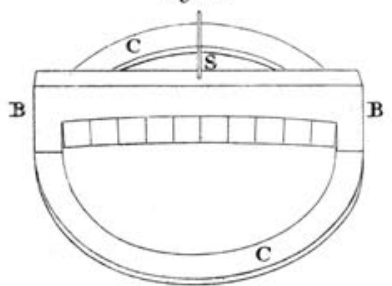

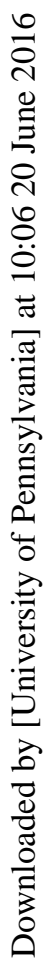
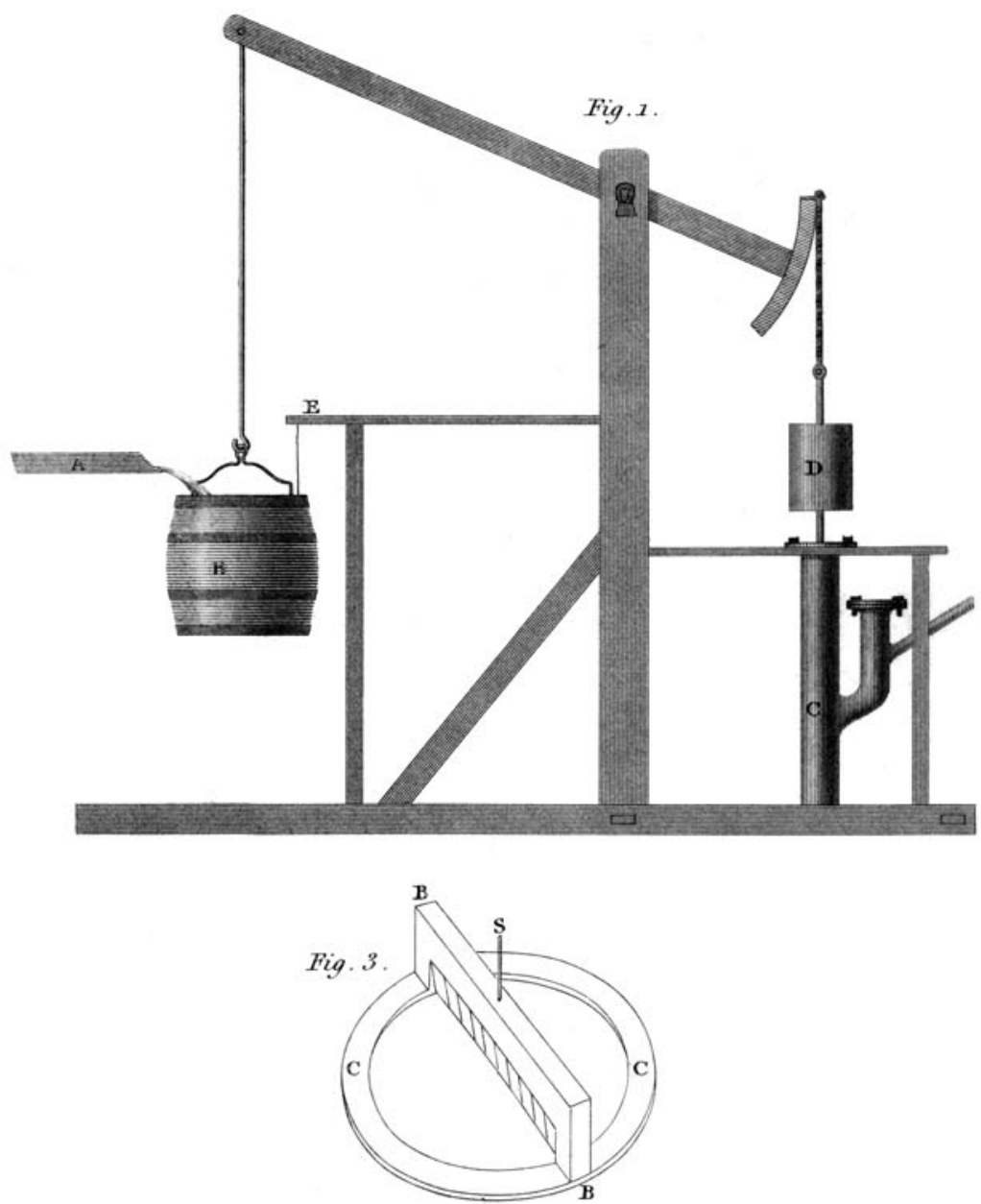
fituation that the Ayle fhall caft no hadow : when this is the cafe the globe will be properly placed; or, as it is ufually called, rectified for the time of day.

This inftrument may alfo be ufed for taking diftances of places or ftars, on different parts of the globe, which are not more than ten degrees afunder.

XVI. A fequ Particulars refpecting Mr. Boaz's Patent Telegrapb*.

THIS Telegraph exhibits the alphabetic or other charakters, or fignals, by means of lamps rendered vifible and invifible by a mechanifm fimple in its conftruction and immediate in its effects, as alfo by boards or other opaque bodies, which may, in like manner, be rendered vifible or invifible at pleafure, by alternately prefenting their fronts or their edges to the eye. Or by lamps and boards fo combined together, that both or either may be ufed: but perhaps the modes eafief in fitting up and application are the following, viz. ;

Twenty-five lamps are placed in a frame at equal diftances from each otber, as reprsfented by the white dots in fig. $I$, No. ', (plate III) each having a moveable cover, or blind, fitted to it, in fuch a manner that, when they fall down, (which they do by their own weight) the lamps, or rather the flames of the lamps, are intercepted and rendered invifible, fo prefenting a mere blank to the eye placed in front of the frame, as in fig. 2, No. 1 .

Another frame is provided having grooves cut in it: and for each letter of the alphabet or other fign wifhed to be exhibited, an oblong piece of wood is alfo provided, made fo as to flide backward and forward in thefe grooves, having an alphabetical letter or other fign, confpicnoufly marked on the outer end of it. Any one of thefe pieces of wood, by being puthed in or drawn out, pulls all at onee from before the lamps, or lets down (by means of ropes or wires) as many lamp-covers or blinds as are neceflary to exhibit that particular letter or fign marked on that particular piece of wood, fo puthed in or drawn out. The letters of the alphabet fo exhibited, are reprefented by figures 3 to 28 , No. I.

The fame thing, however, may be accomplifhed by means of nine lamps only. Fig. 1, No. 2, reprefents the nine lamps, rendered vifible by having their covers or blinds remourd as mentioned above. Fig. 2, No. 2 , reprefents the whole cavered. Figs. 3 to 28 , No. 2, reprefent the whole

\footnotetext{
* Comnunicared by Mr. Boaz.
} 